\title{
Pengaturan dan Tanggungjawab Negara terhadap Global Warming dalam Protokol Kyoto 1997
}

\author{
Virgayanti Fattah
}

Dosen Bagian Hukum Internasional Fakultas Hukum Univ. Tadulako

\begin{abstract}
Abstrak
Metode penelitian hukum normatif yang dilakukan dengan mengkaji data sekunder yang kemudian dianalisis menggunakan teknik analisis deskriptif. Tujuan artikel ini adalah untuk mengetahui tanggungjawab negara terhadap pemanasan global yang diatur dalam Protokol Kyoto 1997. Hasil kajian disimpulkan bahwa, pertama, negara maju dan berkembang memanggul tanggung jawab berbeda, Artinya Semua negara pihak mempunyai tanggung jawab yang sama namun dalam tingkat yang berbeda dalam hal target pengurangan emisi gas rumah kaca. Perbedaan tanggungjawab tersebut, berdasarkan hal target pengurangan emisi gas rumah kaca dan keadaan ekonomi masing-masing negara. Dalam kenyataan, terlihat aspek ketidak adilan dalam penerapan Prinsip Tanggungjawab negara dalam pelaksanaan Protokol Kyoto, karena negara maju sebagai penghasil sebagian besar emisi dan mempunyai kemampuan paling besar untuk mengurangi emisi GRK, tetapi mereka mengambil porsi tanggungjawab yang tidak sesuai dalam menangani perubahan iklim. Kedua, Pelaksanaan Undang-undang Nomor 6 Tahun 1994 tentang Pengesahan United Nations framework Convention on Climate Change dan Undang-Undang No. 17 Tahun 2004 Tentang Pengesahan Kyoto Protocol To The United Nation Framework Convention On Climate Change, seperti undang-undang lain di Indonesia, pelaksanaan kedua undang-undang ini juga lemah.
\end{abstract}

Kata kunci : pemanasan global, dan tanggungjawab negara.

\section{Pendahuluan}

Pemanasan Global adalah isu lingkungan hidup yang dapat mengakibatkan perubahan iklim yang menakutkan. Pemanasan global mulai marak dibicarakan setelah Persatuan Bangsa-Bangsa (PBB) membentuk Intergorvermental Panel on Climate Change (IPCC) pada Tahun 1988. IPCC adalah sebuah panel ilmiah yang terdiri dari para ahli klimatologi untuk mengkaji perubahan iklim yang telah terjadi beberapa tahun terakhir ini. IPCC menyimpulkan bahwa sebagian besar peningkatan temperatur rata-rata global sejak pertengahan abad ke-20, kemungkinan besar disebabkan oleh meningkatnya gas rumah kaca akibat aktifitas manusia. ${ }^{1}$

$$
\text { Berdasarkan Piagam }
$$

Perserikatan Bangsa-Bangsa (PBB)

dan Prinsip-Prinsip Hukum

Internasional, setiap negara diakui memiliki hak berdaulat untuk memanfaatkan sumber daya hayati, sesuai dengan kebijakan bidang lingkungan dan pembangunan masing-masing dan juga berkewajiban menjaga agar kegiatan yang berlangsung di dalam wilayahnya atau berada di bawah pengawasannya tidak menimbulkan kerusakan lingkungan negara lain

\footnotetext{
${ }^{1}$ Gatut Susanta dan Hari Sutjahjo, Akankah Indonesia Tenggelam Akibat Pemanasan Global ? Penebar Plus, Jakarta, 2007, hal.
} 
atau wilayah diluar batas wilayah nasional negara-negara ${ }^{2}$.

Salah satu dari pertemuan yang bersifat internasional adalah pertemuan Kyoto, Jepang pada Tahun 1997. Pertemuan di Kyoto, Jepang tersebut adalah sebuah instrument hukum (legal instrument) yang dirancang untuk mengimplementasikan Konvensi Perubahan Iklim yang bertujuan untuk menstabilkan konsentrasi Gas Rumah $\mathrm{Kaca}^{3}$ agar tidak mengganggu sistem iklim bumi.

Setelah di adopsi pada tanggal 11 Desember Tahun 1997, Protokol Kyoto dibuka untuk ditanda tangani pada tanggal 16 Maret Tahun 1998, menurut syarat-syarat persetujuan bahwa protokol mulai belaku pada hari ke-90 setelah diratifikasi oleh paling sedikit 55 pihak konferensi, termasuk negara-negara maju dengan total emisi karbon dioksida paling sedikit 55\% dari total emisi Tahun 1990 dari kelompok negara-negara industri ini.

Efektifitas Protokol Kyoto ini yang mensyaratkan agar diratifikasi oleh paling sedikit 55 negara menunjukan protokol ini memerlukan partisipasi banyak negara termaksud negara-negara berkembang. Syarat minimum adalah 55\% emisi negara maju harus dilibatkan, menunjukan pentingnya peranan negara maju sebagai pengemisi utama untuk bertindak langsung karena selama ini merekalah yang memberikan kontribusi terbesar dalam peningkatan konsentrasi GRK, maka negara-negara inilah yang memiliki tanggungjawab dan perlu menunjukan kepemimpiannya dalam upaya melindungi bumi,dari syarat

2 Ida Bagus Wyasa Putra, Hukum Lingkungan Internasional, Perspektif Bisnis Intenasional, Refika Aditama, Bandung, 2003, Hal. 40.

${ }^{3}$ Gas Rumah Kaca, Selanjutnya disebut GRK. tersebut. Ratifikasi oleh Rusia pada 18 November Tahun 2004 telah memenuhi syarat 55 persen ${ }^{4}$.

Desember Tahun 2004, Indonesia pada akhirnya meratifikasi Protokol Kyoto melalui UU No. 17 Tahun 2004 dan menindaklanjuti ratifikasi Protokol Kyoto dengan berbagai upaya, diantaranya membentuk institusi seperti DNA (Desagnated National Authority) dengan kordinator dari Kementrian Lingkungan Hidup. Negara-negara yang meratifikasi protokol ini berkomitmen untuk mengurangi emisi/pengeluaran karbon dioksida dan lima GRK atau bekerja sama dalam perdagangan emisi jika mereka menjaga jumlah atau menambah emisi gas-gas tersebut, yang telah dikaitkan dengan pemanasan global.

Tercapai Ketentuan dalam Protokol Kyoto ini, mengenai kewajiban setiap negara harus menurunkan emisi gas rumah kaca dalam level Tahun 1990 sebesar 5\% selama Tahun 2008-2012, diperlukan adanya tanggungjawab dari partisipasi setiap negara untuk saling bekerjasama, karena jika pengurangan emisi ini tidak terwujud akan sangat membawa dampak buruk bagi dunia karena kita tahu bahwa kesadaran akan masa depan manusia bergantung pada masa depan lingkungannya, namun pada kenyataannya meskipun semua negara berkembang meratifikasi Protokol Kyoto ini, tetapi negara maju yang meratifikasinya hanya memberi kontribusi penurunan emisi yang kurang dari " $55 \%$ ".

Dampak buruk yang nanti terjadi tidak disebabkan oleh satu negara saja, seorang individu, sebuah perusahaan, tetapi beberapa aktor yang melakukannya secara bersama dalam jumlah yang berbeda-beda;

\footnotetext{
${ }^{4}$ Daniel Murdiyarso ,2003. Protokol Kyoto, implikasinya bagi Negara berkembang, penerbit buku kompas, Jakarta,hlm 8.
} 
sementara itu kita ketahui bahwa ada beberapa negara yang memiliki cadangan hutan yang luas tapi tidak berkontribusi banyak terhadap pencemaran lingkungan harus menanggung beban menjaga kelestarian hutannya untuk keseimbangan iklim dunia. Sebuah alternatif yang ditawarkan dalam UNFCCC (United Nations Framework Convention on Climate Change) bahwa tanggungjawab itu melekat pada semua negara tetapi dalam proporsi yang berbeda, dikenal dengan 'common but differentiated responsiblities' (CBDR) yang terdapat dalam Pasal 10 Protokol Kyoto Tahun 1997.5

Penggunaan energi merupakan sumber utama terjadinya pemanasan global karena negara kita terikat pada Protokol Kyoto maka kita perlu memperhatikan konsumsi energi kita. Protokol Kyoto merupakan Persetujuan Pelaksana Kerangka Konvensi Perubahan Iklim, mempunyai dampak yang sangat penting bagi Indonesia.

Pemanasan global pada dasarnya merupakan fenomena peningkatan temperatur global dari tahun ke tahun karena terjadinya efek rumah kaca (greenhouse effect) yang disebabkan oleh meningkatnya emisi gas-gas seperti karbondioksida (CO2), metana (CH4), dinitrooksida (N2O) dan CFC sehingga energi matahari terperangkap dalam atmosfer bumi. Berbagai literatur menunjukkan kenaikan temperatur global termasuk Indonesia yang terjadi pada kisaran $1,5-4^{0}$ celcius pada akhir abad $21 .^{6}$

Pemanasan global mengakibatkan dampak yang luas dan serius bagi lingkungan bio-geofisik seperti :

a. Pelelehan es di kutub,

b. Kenaikan muka air laut,

\footnotetext{
${ }^{5}$ www.sihar dejournal.wordpress.com

${ }^{6}$ www.physics.ius.indiana.edu.com
}

c. Perluasan gurun pasir,

d. Peningkatan hujan dan banjir,

e. Perubahan iklim,

f. Punahnya flora dan fauna tertentu,

g. Migrasi fauna dan hama penyakit, dsb.

Sedangkan dampak bagi aktivitas sosial-ekonomi masyarakat meliputi:

a. Gangguan terhadap fungsi kawasan pesisir dan kota pantai,

b. Gangguan terhadap fungsi prasarana dan sarana seperti jaringan jalan, pelabuhan dan bandara

c. Gangguan terhadap permukiman penduduk,

d. Pengurangan produktivitas lahan pertanian,

e. Peningkatan resiko kanker dan wabah penyakit, dsb.

Efek Rumah Kaca dapat divisualisasikan sebagai sebuah proses yang pada kenyataannya, di lapisan atmosfer terdapat selimut gas. Rumah kaca adalah analogi atas bumi yang dikelilingi gelas kaca. Panas matahari masuk ke bumi dengan menembus gelas kaca tersebut berupa radiasi gelombang pendek. Panas matahari tersebut, sebagian diserap oleh bumi dan sisanya dipantulkan kembali ke angkasa sebagai radiasi gelombang panjang, namun, panas yang seharusnya dapat dipantulkan kembali ke angkasa menyentuh permukaan gelas kaca dan terperangkap di dalam bumi. Layaknya proses dalam rumah kaca di pertanian dan perkebunan, gelas kaca memang berfungsi menahan panas untuk menghangatkan rumah kaca.

Aktivitas manusia menyebabkan peningkatan konsentrasi selimut gas di atmosfer sehingga melebihi konsentrasi yang seharusnya, maka panas matahari yang tidak dapat dipantulkan ke angkasa akan meningkat pula. Semua proses itulah yang disebut Efek Rumah Kaca. Pemanasan global dan perubahan iklim merupakan dampak 
dari Efek Rumah Kaca. Para ilmuan memperkirakan bahwa selama pemanasan global, daerah bagian utara dari belahan bumi utara (Northern Hemisphere) akan memanas lebih dari daerah-daerah lain di bumi. Gunung-gunung es akan mencair dan daratan akan mengecil, akan lebih sedikit es yang terapung di perairan utara tersebut, sebagai salah satu akibatnya. Pegunungan di daerah subtropis, bagian yang ditutupi salju akan semakin sedikit serta akan lebih cepat mencair dan musim tanam akan lebih panjang di beberapa daerah.

Temperatur pada musim dingin dan malam hari akan cenderung untuk meningkat. Daerah hangat akan menjadi lebih lembab karena lebih banyak air yang menguap dari lautan. Para ilmuan belum begitu yakin apakah kelembaban tersebut malah akan meningkatkan atau menurunkan pemanasan yang lebih jauh lagi. Hal ini disebabkan karena uap air merupakan gas rumah kaca, sehingga keberadaannya akan meningkatkan efek insulasi pada atmosfer. Uap air yang lebih banyak juga akan membentuk awan yang lebih banyak, sehingga akan memantulkan cahaya matahari kembali ke angkasa luar, di mana hal ini akan menurunkan proses pemanasan.

Kelembaban yang tinggi akan meningkatkan curah hujan, secara rata-rata, sekitar 1\% untuk setiap derajat Fahrenheit pemanasan. (curah hujan di seluruh dunia telah meningkat sebesar 1\% dalam seratus tahun terakhir ini). Badai akan menjadi lebih sering. Air akan lebih cepat menguap dari tanah, akibatnya beberapa daerah akan menjadi lebih kering dari sebelumnya. Angin akan bertiup lebih kencang dan mungkin dengan pola yang berbeda. Topan badai (hurricane) yang memperoleh kekuatannya dari penguapan air, akan menjadi lebih besar. Pola cuaca menjadi tidak terprediksi dan lebih ekstrim.
Pemanasan global ini mengakibatkan timbulnya kerjasama internasional untuk mensukseskan pengurangan gas-gas rumah kaca. Di Tahun 1992, pada Earth Summit di Rio de Janeiro, Brazil, 150 negara berikrar untuk menghadapi masalah GRK dan setuju untuk menterjemahkan maksud ini dalam suatu perjanjian yang mengikat.

Tahun 1997, para perwakilan dari 160 negara merumuskan persetujuan Protokol Kyoto, mereka bertemu secara reguler untuk menegoisasikan isu-isu yang belum terselesaikan seperti peraturan, metode dan pinalti yang wajib diterapkan pada setiap negara untuk memperlambat emisi GRK. Para negoisator merancang sistem di mana suatu negara yang memiliki program pembersihan yang sukses dapat mengambil keuntungan dengan menjual hak polusi yang tidak digunakan ke negara lain. Sistem ini disebut perdagangan karbon, contoh, negara yang sulit meningkatkan lagi hasilnya, seperti Belanda, dapat membeli kredit polusi di pasar, yang dapat diperoleh dengan biaya yang lebih rendah. Rusia, merupakan negara yang memperoleh keuntungan bila sistem ini diterapkan. Perjanjian ini, menyerukan kepada 38 negaranegara industri yang memegang persentase paling besar dalam melepaskan GRK untuk memotong emisi mereka ke tingkat 5\% di bawah emisi Tahun 1990. Pengurangan ini harus dapat dicapai paling lambat Tahun 2012.

Pemanasan global juga sering dikaitkan dengan perubahan iklim. Trenberth, Houghton and Filho $^{7}$ mendefinisikan perubahan iklim sebagai perubahan pada iklim yang dipengaruhi langsung atau tidak

\footnotetext{
${ }^{7}$ Addinul Yakin, Ekonomi Sumberdaya dan Lingkungan, Teori dan Kebijaksanaan Pembangunan Berkelanjutan, Akademika Pressindo, Jakarta, 2002
} 
langsung oleh aktivitas manusia yang merubah komposisi atmosfer yang akan memperbesar keragaman iklim teramati pada periode yang cukup panjang.

Kerangka Konvensi Perubahan Iklim belum mencapai persetujuan tentang berapa besarnya pengurangan emisi GRK Antropogenik, yang disetujui dalam Kerangka Konvensi Perubahan Iklim adalah Tanggung Jawab Differential ${ }^{8}$ antara negara dan negara dengan ekonomi dalam transisi.

Negara Annex 1 mempunyai tujuan untuk mengurangi emisinya sedangkan Negara non-annex tidak (atau belum) mempunyai tanggung jawab tersebut. Protokol Kyoto 1997 kemudian menyetujui bahwa negara Annex 1 dalam komitmen antara Tahun 2008 sampai Tahun 2012 akan mengurangi emisinya dengan minimal 5\% dibawah emisi Tahun 1990 .

Kerangka Konvensi Perubahan Iklim mengatur tentang pengurangan emisi oleh negara Annex 1 dapat dilakukan berpatungan (Jointly) dengan pihak lain dan dapat membantu pihak lain untuk mencapai tujuan konvensi ${ }^{10}$. Berdasarkan ketentuan tersebut, dalam Protokol Kyoto terdapat 3 (tiga) mekanisme untuk mitigasi perubahan iklim, yaitu:

1. Implementasi Patungan (IP) atau Joint Implementation (JI) antara negara Annex 1.

2. Mekanisme Pembangunan Bersih (MPB) atau Clean Development Mecanism (CDM) antara negara Annex 1 dengan negara NonAnnex 1.

\footnotetext{
8 Tanggungjawab Differensial tersebut, antara negara dengan negara yang ekonominya dalam transisi. Eksplisit disebut dengan Annex I dan negara sedang berkembang.

9 Persetujuan ini tertera pada Artikel 3.Paragraf 1. Protokol Kyoto 1997

10 Artikel 4.Paragraf 2 (a) Konvensi Perubahan Iklim 1992.
}

3. Perdagangan Emisi Internasional (PEI) atau International Emissions Trading (IET) antara negara Annex 1.

Ketiga mekanisme tersebut bersifat fleksibel, ketiganya terbuka untuk badan pemerintah atau badan swasta ${ }^{11}$.

Implementasi Patungan (IP) yang dimaksud adalah negara Annex 1 manapun dapat memindahkan (Transfer) atau mendapatkan (Acquire) dari pihak negara Annex 1 manapun unit reduksi emisi dari proyek yang bertujuan untuk mengurangi emisi atau pada sumber emisi atau memperbesar kemampuan rosot (Sink) untuk mengikat GRK dalam sektor ekonomi manapun ${ }^{12}$.

Artikel 1 Paragraf 2 Protokol Kyoto menyatakan bahwa Mekanisme Pembangunan Bersih (MPB) merupakan mekanisme yang khusus mengatur perdagangan dengan negara sedang berkembang. MPB pada satu pihak bertujuan untuk membantu negara sedang berkembang untuk memberi kontribusi tercapainya standarisasi kadar GRK dalam atmosfer. Bantuan tersebut berupa pemindahan teknologi dan dana dari negara maju kepada negara sedang berkembang untuk melakukan pembangunan berkelanjutan. MPB tidak menghambat usaha pembangunan negara Non-Annex melainkan justru membantu. MPB berasal dari inisiatif negara Non-Annex yang mendapat dukungan luas dan kuat dari negarnegara sedang berkembang13.

11 Otto Soemarwoto, Atur Diri Sendiri : Paradigma Baru Pengelolaan Lingkungan Hidup. Pembangunan Ramah Lingkungan : Berpihak Pada Rakyat, Ekonomis dan Berkelanjutan, Gajah Mada University Press, Jakarta, 2001, Hal. 141.

${ }^{12}$ Artikel 6 Paragraf 1 Protokol Kyoto.

${ }^{13}$ Walaupun Artikel 6 Paragraf 1 Protokol Kyoto sebenarnya hanya mengatur IP antara negara Annex 1, namun dalam praktek telah terjadi pula perdangan antara negara Annex 
Protokol Kyoto menyajikan peluang untuk mengubah taman nasional, cagar alam dan hutan lindung dari pos biaya dalam anggaran pendapatan dan biaya daerah menjadi pos pendapatan. Proyek MPB dengan Reduksi Emisi ber-Sertifikat (RES)nya merupakan potensi untuk meningkatkan Pendapatan Asli Daerah (PAD) tanpa harus mengeksploitasi secara fisik hutan tersebut.

Indonesia juga telah melakukan aksi nyata dalam menyikapi pemanasan global ini, ini dibuktikan dengan adanya kegiatan melakukan penanaman melalui "Program Kampanye Indonesia Menanam, Kecil Menanam Dewasa Memanen", Rehabilitasi Hutan dan Lahan, Aksi Penanaman Serentak, Gerakan Perempuan Tanam dan Pelihara Pohon, dilanjutkan dengan adanya pertemuan internasional di Provinsi Bali yaitu Conference of Parties (COP) 13 United Nation Framework Convention On Climate Change (UNFCCC) pada tanggal 3 s/d 14 Desember Tahun 2007 yang dihadiri oleh 103 negara dengan 9000 peserta.

Berdasarkan penjelasan di atas, maka dirumuskanlah sebuah permasalahan, yaitu Bagaimana Pengaturan dan tanggungjawab negara terhadap Global Warming dalam Protokol Kyoto 1997?

\section{Pembahasan}

\subsection{Pengaturan Global Warming Berdasarkan Protokol Kyoto Tahun 1997}

Berdasarkan Resolusi Majelis Umum PBB 2398 (XXIII) tentang United Nations Conference on the Human Environment, PBB menyelenggarakan Konferensi Lingkungan Hidup di Stockholm 5-16 Juni Tahun 1972. Konferensi ini

1 dengan negara Non-Annex, mis. Meksiko dengan Kosta Rika, padahal secara resmi perdagangan berlaku. besifat "Action Oriented" yaitu berorientasi kepada tindakantindakan praktis untuk melindungi lingkungan. Konferensi ini menghasilkan sebuah deklarasi, yaitu Deklarasi Stockholm Tahun 1972 (Declaration of the United Nations Conference on the Human Environtment) yang memuat 26 Prinsip pengelolaan dan perlindungan lingkungan, 109 rekomendasi, termasuk system kelembagaan yang bertanggung jawab terhadap pelaksanaan deklarasi.

Tiga belas tahun setelah Deklarasi Stockholm Tahun 1972, masyarakat internasional kembali menyelenggarakan berbagai pertemuan $^{14}$, salah satunya adalah pertemuan yang diselenggarakan di Wina pada tanggal 18-22 Maret Tahun 1985 dan menghasilkan sebuah Konvensi Tentang Perlindungan Ozon (Vienna Convention for the Protection of the Ozone Layer) ${ }^{15}$. Pertemuan ini dilanjutkan dengan pertemuan Montreal, 14-16 September Tahun 1987 dan menghasilkan ketentuan tambahan untuk Konvensi Wina Tahun 1985, yaitu Protokol Montreal Tahun 1987 (Protocol on Substances that Deplete the Ozon Layer).

Pertemuan selanjutnya diselenggarakan di Rio de Jeneiro tangal 3-14 Juni Tahun 1992, United Nations Conference on Environment and Development, yaitu suatu pertemuan yang dimaksudkan untuk secara lebih menyeluruh membahas

\footnotetext{
14 Negara-negara Amerika Selatan menyelenggarakan pertemuan di Manaus, Brazil pada tanggal 6 Mei 1989, menghasilkan The Amazone Declaration 1989., kemudian pada tahun yang sama, atas inisiatif Perancis, Norwegia dan Nederland, telah diselenggarakan pertemuan di The Haque pada tanggal 11 Maret 1989, menghasilkan Haque Declaration on the Environment tahun 1989.

${ }^{15}$ UNGA Resolution on Protection of Global Climate for Present and Future Generations of Mankind, December 6, 1988.
} 
dan mengatur masalah lingkungan global. Hasil puncak dari keseluruhan pertemuan itu adalah berbagai rancangan konvensi yang berkaitan dengan perlindungan lingkungan global, seperti Konvensi tentang Perlindungan Keanekaragaman Hayati, Konvensi Perubahan Iklim dan Konvensi tentang Pelestarian Hutan Tropis ${ }^{16}$.

Dua elemen lingkungan global yang menapat perhatian khusus dalam Konferensi Rio 1992, adalah 1) Stabilitas Iklim; dan2) Keragaman Hayati.

Konvensi Perubahan Iklim dibentuk untuk menjaga keseimbangan konsentrasi GRK ${ }^{17}$ pada lapisan atmosfir, yaitu sampai tingkat "tidak menimbulkan dampak terhadap iklim". Salah satu tindakan untuk mengimplementasikan Konvensi Perubahan Iklim, maka diambillah tindakan yaitu mengadopsi Protokol Kyoto adalah sebuah instrument hukum (legal instrument) yang merupakan Persetujuan Pelaksana Kerangka Konvensi Perubahan Iklim, bertujuan untuk menstabilkan konsentrasi GRK agar tidak mengganggu sistem iklim bumi dan mempunyai dampak yang sangat penting untuk Indonesia.

Protokol Kyoto diadopsi pada tanggal 11 Desember Tahun 1997, dibuka untuk ditandatangani pada tanggal 16 Maret Tahun 1998 dan

\footnotetext{
${ }^{16}$ Atas inisiatif WMO, UNEP, ICSU, telah diselenggarakan pertemuan di Villach, Austria Tahun 1987 untuk membahas tentang Pemanasan Global, kemudian berlanjut pada tahun 1988 UNEP dan WMO membentuk IPCC (Intergovernmental Panel on Climate Change). Pada Bulan November Tahun 1990, sebanyak 157 negara mengadakan pertemuan di Genewa, membahas tentang hal yang sama.

17 Gas Rumah Kaca adalah “... thoses gaseous constituens of the atmosphere, both natural and anthropogenic, that absorb and re-emit infrared radiation..." Pasal 1 Paragraf 5 Konvensi Perubahan Iklim 1992
}

mulai diterapkan pada tanggal 16 Februari $2005^{18}$. Mencapai Tahun 2008, ada 183 negara yang telah meratifikasi Protokol Kyoto. Ini berarti bahwa negara-negara yang telah meratifikasi Protokol Kyoto tersebut harus mengikuti segala aturan yang tertulis dalam Protokol dan bersedia menerima sanksi jika melanggar. ${ }^{19}$

Banyak pakar berpendapat walaupun sudah ada prosedur untuk implementasinya, Protokol Kyoto dapat dikatakan belum efektif dapat mengurangi emisi GRK. Hal ini karena ,jumlah negara maju yang meratifikasi belum memenuhi persyaratan. Saat ini 109 negara sudah meratifikasinya, tetapi emisi 24 negara maju yang terdapat di dalamnya baru mencapai $43 \%$, padahal, baru dapat dikatakan efektif apabila pengurangan emisi minimum 55\%. Salah satu pertemuan PBB, wakil dari Brazil mengatakan bahwa emisi justru meningkat dua kali lipat dibandingkan ketika Konvensi Perubahan Iklim ditandatangani pada Tahun 1992.

Alasan utama mengapa kesepakatan iklim tidak efektif adalah karena kedua perjanjian ini sebenarnya tidak merundingkan secara lugas pengurangan emisi dan sebaliknya keduanya adalah bagian dari tawar-menawar yang lebih luas antara negara-negara kaya dan negara miskin, perebutan sumberdaya dan hak untuk menggunakan energi, dan persaingan ekonomi. ${ }^{20}$

Sejak di adopsi, hingga saat ini protokol Kyoto belum kunjung efektif. Ketidak-efektifan ini karena mundurnya Amerika Serikat dari meratifikasi protokol ini, sedangkan kita ketahui bahwa negara industri

\footnotetext{
${ }^{18}$ Ida Bagus Wyasa Putra, Op. Cit, hal.22

${ }^{19}$ Menurut syarat persetujuan, protokol ini mulai berlaku pada hari ke-90 setelah diratifikasi ole paling sedikit 55 negara pihak.

${ }^{20}$ www.beritadunialingkungan.com
} 
terbesar dalam pembuangan emisi adalah Amerika Serikat dengan jumlah $36,1 \%$.

Amerika Serikat merupakan negara yang paling berpengaruh pada kebijakan yang dirancang diperserikatan bangsa-bangsa, salah satu contoh adalah hasil Protokol Kyoto ini, dalam artian kalau semua kebijakan yang disepakati PBB menguntungkan Amerika Serikat maka akan diratifikasinya namun bila kesepakatan tersebut merugikan negaranya, maka akan ditolaknya. Penolakan yang diajukan oleh Amerika Serikat merupakan salah satu dari penolakan beberapa negara yang mempunyai komitmen, termasuk di antaranya beberapa negara maju.

Kenyataanya, yang membuat negara-negara maju memberikan komitmen terhadap Protokol Kyoto adalah usulan yang diajukan oleh Alliance of Small Island States (AOSIS) pada Tahun 1994 yang dikenal dengan nama Target Toronto. AOSIS mengusulkan agar para pihak yang termasuk dalam Annex I Konvensi Perubahan Iklim menurunkan emisi CO2nya sebesar $20 \%$ pada Tahun 2005 , sementara negara maju yang mengajukan usulan adalah Jerman pada tahun 1996 dengan target sebesar 10\% menjelang Tahun 2005 dan 15\% menjelang Tahun 2010.

Jerman telah mendapatkan persetujuan dari anggota $E U$ (Uni Eropa) lainnya mengenai target waktunya, tetapi persen penurunnya Jerman sendiri. Setahun kemudian akhirnya $E U$ menyepakati penurunan emisi tiga macam gas ( $\mathrm{CO} 2, \mathrm{CH} 4$, dan N20) sebesar 7,5\% pada Tahun 2005 sampai Tahun 2010 dengan menggunakan Tahun 1999 sebagai tahun awal. ${ }^{21}$

\footnotetext{
${ }^{21}$ Supriadi, Hukum Lingkungan Internasional, Penerbit Sinar Grafika, 2006, hal. 71
}

Jepang adalah negara pertama yang secara konkret mengusulkan pembedaan target (differentiated target) penurunan emisi untuk setiap negara. Usul yang dimulai dengan target $5 \%$ ini dan kemudian disesuaikan berdasarkan pertumbuhan ekonomi dan penduduk, ternyata emisi global hanya akan stabil pada tingkat emisi pada Tahun 1990.

Adanya taget penurunan emisi ini, maka sasaran Protokol Kyoto adalah :

a. Mengikat secara hukum (legally binding).

$b$. Adanya periode komitmen (commitmen period).

c. Digunakannya jatah emisi (assigned amount) setiap pihak Annex 1.

d. Diamasukannya enam jenis GRK (basket of gases).22

Sukses diberlakukan, Protokol Kyoto diprediksi akan mengurangi rata-rata pemanasan global antara $0,02 \hat{\mathrm{A}}^{\circ} \mathrm{C}$ dan $0,28 \hat{\mathrm{A}}^{\circ} \mathrm{C}$ pada Tahun 2050. Hingga Februari Tahun 2005, 141 negara telah meratifikasi protokol tersebut, termasuk Kanada, Tiongkok, India, Jepang, Selandia Baru, Rusia, 25 negara anggota Uni Eropa, serta Rumania dan Bulgaria. Tercapai Tujuan Protokol Kyoto ini, maka semua negara terus menciptakan teknologi yang ramah lingkungan, terutama negara maju, karena, negara maju yang banyak mengeluarkan $\mathrm{CO} 2$ penyebab rumah kaca.

Mengedepankan Protokol Kyoto, industri-industri stategis seperti industri migas, industri transportasi, industri minyak dan gas didorong untuk menggunakan energi alternatif yang ramah lingkungan, artinya, sedapat mungkin meninggalkan penggunaan migas yang merupakan sumber utama emisi gas karbon. 5 (lima) besar negara

22 ibid 
penyumbang emisi GRK terbesar adalah 1) Amerika Serikat; 2. Tiongkok; 3. Rusia; 4. India; dan 5. Jepang

Sejumlah negara industri maju seperti Amerika Serikat dan Australia hingga kini belum menandatangi protokol ini. Mereka beranggapan, kesepakatan ini akan mengancam masa depan industi mereka, padahal AS tercatat sebagai salah satu negara penyumbang emis gas karbon terbesar di dunia.

Indonesia telah meratifikasi kedua kesepakatan iklim melalui Undang-Undang No.6 Tahun 1994 tentang Pengesahan United Nations Framework Convention on Climate Change (Konvensi Kerangka Kerja Perserikatan Bangsa-Bangsa tentang Perubahan Iklim) dan UndangUndang No. 17 Tahun 2004 tentang Pengesahan Kyoto Protocol to The United Nations Framework Convention on Climate Change (Protokol Kyoto atas Konvensi Kerangka Kerja PBB tentang Perubahan). Pemerintah Indonesia setelah meratifikasi Protokol Kyoto, kemudian menyusun Rencana Aksi Nasional Mitigasi dan Adaptasi Perubahan Iklim, tetapi seperti banyak UU lain di Indonesia, pelaksanaan kedua UU ini juga lemah. ${ }^{23}$

Bali menjadi tempat Konferensi Para Pihak atau COP 13 UNFCCC dan pertemuan para pihak atau meeting of the Parties (MOP) ke-3 Protokol Kyoto (disingkat COP13/CMP3). Konferensi ini amat penting karena diharapkan menghasilkan semacam Bali Mandate yang menjadi pedoman bagi pembahasan mengenai pengurangan emisi GRK di masa mendatang karena kesepakatan pengurangan emisi periode pertama dalam Protokol Kyoto akan berakhir pada Tahun 2012.

\footnotetext{
${ }^{23}$ www.rki.kbs.co.kr/indonesian/news/news_ issue_detail.com
}

$\begin{array}{ccc}\begin{array}{c}\text { Dunia } \\ \text { pemimpin }\end{array} & \begin{array}{c}\text { mengharapkan } \\ \text { negara-negara }\end{array} & \begin{array}{c}\text { para } \\ \text { akan }\end{array}\end{array}$ menyepakati butir-butir perundingan yang menjadi landasan bagi perundingan kesepakatan pengurangan emisi di masa datang. Hal ini diperlukan demi keselamatan bumi dan seluruh isinya. Karena itu Bali menjadi sorotan dunia pada Desember Tahun 2007.

Kesepakatan pasca Tahun 2012 dianggap sebagai yang terpenting COP13/CMP3 di Bali akan membahas banyak isu penting lain, diantaranya:

1. Dana dan Pelaksanaan Program Adaptasi Perubahan Iklim. Negara berkembang perlu melaksanakan program adaptasi terhadap perubahan iklim dengan mempersiapkan diri menghadapi kemungkinan bencana seperti badai tropis, banjir, kekeringan, longsor, abrasi, erosi, dan gangguan kesehatan akibat perubahan iklim. Program tersebut memerlukan dana, sementara negara berkembang juga masih dalam proses melaksanakan pembangunan. Karena itu, perlu dirundingkan penyediaan dana tambahan oleh negara maju serta mekanisme yang adil untuk mengakses dana tersebut.

2. Pengurangan Emisi dari Kerusakan Hutan di Negara Berkembang/ Reducing Emission from Deforestation in Developing Country (REDD).

3. Selama ini, upaya pelestarian hutan tidak diperhitungkan sebagai upaya mengurangi emisi, tetapi perusakan hutan, terutama melalui kebakaran, dihitung sebagai peningkatan emisi. Karena itu diperlukan pengaturan yang lebih adil bagi negara-negara yang kaya hutan dalam memperhitungkan sumberdaya hutan sebagai aset untuk mitigasi emisi GRK. Beberapa hal penting adalah: 
a. Memasukkan AD (Avoided Deforestation atau pencegahan kerusakan hutan) agar dipertimbangkan sebagai program pengurangan emisi.

b. Mekanisme pendanaan oleh pasar (dibiayai oleh swasta) dan non-pasar (dibiayai pemerintah)

c. Pengelolaan Hutan Berkelanjutan/ Sustainable Forest Management (SFM) baik pada hutan buatan maupun hutan alami, dan rehabilitasi lahan melalui aforestasi dan reforestasi agar diperhitungkan sebagai program pengurangan emisi.

4. Transfer Teknologi

Negara maju berkewajiban melaksanakan alih teknologi yang ramah lingkungan kepada negara berkembang sesuai ketentuan dalam kedua kesepakatan iklim ini. Namun hal itu belum diwujudkan sama sekali. Bila negara berkembang diminta berpartisipasi dalam pengurangan emisi GRK, maka salah satu alat penting adalah teknologi yang dikuasai oleh perusahaan perusahaan besar di negara maju. Tanpa alih teknologi negara berkembang akan kesulitan melaksanakan kewajibannya sesuai kesepakatan iklim. ${ }^{24}$

\subsection{Tanggung Jawab Negara Terhadap Pemanasan Global}

Perbedaan antara konvensi dan protokol adalah, Konvensi seperti undang-undang dan Protokol adalah penjabaran langkah-langkah lebih rinci dan spesifik untuk mencapai tujuan dari undang-undang layaknya sebuah peraturan pemerintah. jadi Protokol Kyoto adalah penjabaran sebagian ketentuan dalam Konvensi Perubahan Iklim. Negara yang meratifikasi sebuah protokol akan

${ }^{24}$ www.walhibali.org. terikat secara hukum untuk melaksanakan ketentuan di dalamnya. ${ }^{25}$

Pasal 3 Konvensi Perubahan Iklim mencantumkan Prinsip-prinsip dasar, yaitu:

1. Kesetaraan (Equity). Iklim global dan sistem iklim dimiliki secara adil dan setara oleh semua umat manusia, termasuk generasi mendatang.

2. Tanggung jawab bersama tapi berbeda (Common but differentiated responsibilities). Semua negara pihak mempunyai tanggung jawab yang sama namun dalam tingkat yang berbeda dalam hal target pengurangan emisi gas rumah kaca. Sampai sekarang sebagian besar emisi dihasilkan negara maju, dan mempunyai kemampuan paling besar untuk mengurangi emisi GRK, maka mereka harus mengambil porsi tanggung jawab paling besar dalam menangani perubahan iklim.

3. Tindakan kehati-hatian (Precautionary measure). Apabila ada ancaman kerusakan yang serius, ketiadaan kepastian ilmiah tidak boleh digunakan sebagai alasan untuk menunda tindakan pencegahan. Dunia tidak bisa menunggu hasil kajian ilmiah yang mutlak tanpa melakukan sesuatu untuk mencegah dampak pemanasan global lebih lanjut.

4. Pembangunan Berkelanjutan. Meski secara mendasar prinsip pembangunan berkelanjutan ini masih dalam perdebatan, namun dapat digambarkan sebagai "Pembangunan yang memenuhi kebutuhan saat ini tanpa mengurangi kemampuan generasi mendatang untuk memenuhi kebutuhan mereka pula". Semua negara mempunyai hak dan kewajiban untuk melaksanakan pembangunan berkelanjutan.

${ }^{25}$ www.untreaty.un.org 
Perwujudan dari konvensi tersebut Protokol Kyoto menyatakan bahwa negara Annex 1 pada Konvensi Perubahan Iklim harus mengurangi emisi melalui kebijakan dan langkahlangkah di dalam negeri, antara lain meningkatkan efisiensi penggunaan energi, perlindungan perosot (peresap) GRK, teknologi yang ramah iklim dsb.

Cara untuk memudahkan negara maju memenuhi sasaran penurunan Emisi, Protokol Kyoto juga mengatur mekanisme fleksibel, yakni:

1. Implementasi Bersama Uoint Implementation);

2. Perdagangan Emisi (Emission Trading);

3. Mekanisme Pembangunan Bersih (Clean Development MechanismCDM)

Tiga Mekanisme tersebut diatas Mekanisme Pembangunan Bersih (Clean Development Mechanism-CDM) merupakan mekanisme yang paling efektif sebagai perwujudan dari prototokol Kyoto tersebut, disisi lain CDM adalah mekanisme dibawah Kyoto Protocol/UNFCCC, yang dimaksudkan untuk :

a. Membantu negara maju/industri memenuhi sebagian kewajibannya menurunkan emisi GHGs;

b. Membantu negara berkembang dalam upaya menuju pembangunan berkelanjutan dan kontribusi terhadap pencapaian tujuan Konvensi Perubahan Iklim (UNFCCC).

Beberapa tahun setelah Konvensi Perubahan Iklim (UNFCCC) ditanda-tangani pada tahun 1992, upaya nyata pengurangan emisi GRK (GHGs), sebagai akibat aktifitas manusia belum dapat ditunjukkan. Pada Conference of the Parties (COP)-3 tahun 1997 di Kyoto dicetuskanlah suatu protokol yang menawarkan flexibility mecanism, yang memungkinkan negara-negara industri memenuhi kewajiban pengurangan emisi GRK-nya melalui kerjasama dengan negara lain baik berupa investasi dalam emission reduction project maupun carbon trading.

Dibawah Protokol Kyoto, negara-negara industri diharuskan menurunkan emisi GRK minimal 5\% dari tingkat emisi Tahun 1990, selama Tahun 2008-2012. CDM adalah satusatunya mekanisme dibawah Protokol Kyoto, yang menawarkan win-win solution antara negara maju dengan negara berkembang dalam rangka pengurangan emisi GRK, dimana negara maju menanamkan modalnya di negara berkembang dalam proyekproyek yang dapat menghasilkan pengurangan emisi GRK, dengan imbalan CER (Certified Emission Reductions).

\section{Simpulan}

Tanggung Jawab Negara Terhadap Pemanasan Global, Negara maju dan Negara berkembang memanggul Tanggung Jawab Berbeda, Artinya Semua negara pihak mempunyai tanggung jawab yang sama namun dalam tingkat yang berbeda dalam hal target pengurangan emisi gas rumah kaca. Perbedaan tanggungjawab tersebut, berdasarkan hal target pengurangan emisi gas rumah kaca dan keadaan ekonomi masing-masing negara.

Dalam kenyataan, terlihat aspek ketidak adilan dalam penerapan Prinsip Tanggungjawab negara dalam pelaksanaan Protokol Kyoto, karena negara maju sebagai penghasil sebagian besar emisi dan mempunyai kemampuan paling besar untuk mengurangi emisi GRK, tetapi mereka mengambil porsi tanggungjawab yang tidak sesuai dalam menangani perubahan iklim.

Pelaksanaan Undang-undang Nomor 6 Tahun 1994 tentang Pengesahan United Nations framework Convention on Climate Change dan 
Undang-Undang No. 17 Tahun 2004 Tentang Pengesahan Kyoto Protocol To The United Nation Framework Convention On Climate Change, seperti undang-undang lain di Indonesia, pelaksanaan kedua undang-undang ini juga lemah.

\section{Daftar Pustaka}

Murdiyarso Daniel, 2003, Protokol Kyoto, Implikasinya bagi Negara Berkembang, Penerbit Buku Kompas, Jakarta.

Soemarwoto Otto, 2001, Atur Diri Sendiri : Paradigma Baru Pengelolaan Lingkungan Hidup. Pembangunan Ramah Lingkungan : Berpihak Pada Rakyat, Ekonomis dan Berkelanjutan, Gajah Mada University Press, Jakarta.

Supriadi, 2006. Hukum Lingkungan Internasional, Jakarta Penerbit Sinar Grafika.

Susanta Getut dan Sutjahjo Hari , 2007, Akankah Indonesia Tenggelam Akibat Pemanasan Global? Jakarta, Penebar Plus.

Wyasa Putra Ida Bagus, 2003, Hukum Lingkungan Internasional, Perspektif Bisnis Intenasional, Refika Aditama, Bandung.

Yakin Addinul, 2002, Ekonomi Sumberdaya dan Lingkungan, Teori dan Kebijaksanaan Pembangunan Berkelanjutan Akademika Pressindo, Jakarta

Resolusi Majelis Umum PBB 2398 (XXIII) tentang United Nations Conference on the Human Environment

Declaration of the United Nations Conference on the Human Environtment 1972

Vienna Convention for the Protection of the Ozone Layer 1985

United Nation Framework on Confention Climate Change 1992 - UNFCCC (Konvensi Kerangka kerja PBB tentang Perubahan Iklim ).
Kyoto Protocol to the United Nations Framework Convention on Climate Change 1997 (Protokol Kyoto mengenai Konvensi Rangka Kerja PBB tentang Perubahan Iklim)

Undang-Undang Nomor 6 Tahun 1994 tentang Pengesahan United Nations framework Convention on Climate Change

Undang-Undang Nomor 17 Tahun 2004 Tentang Pengesahan Kyoto Protocol To The United Nation Framework Convention On Climate Change

www.sihar dejournal.wordpress.com www.physics.ius.indiana.edu.com www.rki.kbs.co.kr/indonesian/news/n ews_issue_detail.com

www.walhibali.org

www.Iklimkarbon.com

www.untreaty.un.org www.cdmasean.pelangi.or.id www.huk-ling.org. 